\title{
Marine Technology Transfer
}

\author{
Towards a Capacity-Building Toolkit for Marine Biodiversity beyond \\ National Jurisdiction
}

\author{
Harriet Harden-Davies
}

\begin{abstract}
The transfer of marine technology and capacity building are inextricably linked under the United Nations Convention on the Law of the Sea (UNCLOS). The UNCLOS framework for the transfer of marine technology includes several elements related to scientific research, such as: scientific training; access to research equipment; and sharing information, data and knowledge. These elements are important tools for capacitybuilding to enable a science-based approach to the conservation and sustainable use of biodiversity beyond national jurisdiction (вв NJ). However, there are well-known gaps and weaknesses in the international framework for implementing the transfer of marine technology. Several initiatives are already underway through the Intergovernmental Oceanographic Commission of Unesco that attempt to close the gap in capacity. These initiatives could provide a basis for a B BNJ agreement to build on and to contribute to the imminent United Nations Decade of Ocean Science for Sustainable Development 2021-2030. This paper examines the UnCLOs framework for marine technology transfer and the challenges and potential opportunities to enhance the implementation of transfer of marine technology in order to build capacity for the conservation and sustainable use of BBNJ are proposed.
\end{abstract}

\section{Keywords}

marine scientific research - law of the sea - technology transfer - capacity building biodiversity beyond national jurisdiction - high seas

\section{Introduction}

Science continues to be a critical ingredient in the ongoing development of a new international legally binding instrument for the conservation and 
sustainable use of marine biological diversity of areas beyond national jurisdiction (ввNJ agreement) under the United Nations Convention on the Law of the Sea (UNCLOS). ${ }^{1}$ Scientific investigation has only just begun to unveil the full extent of biodiversity in areas beyond national jurisdiction (ABNJ). Rapid advances in science and technology have revealed new discoveries of species and ecosystems in the deep ocean, such as 120,000-year-old hydrothermal vents and 4,00o-year-old corals. ${ }^{2}$ Such discoveries of awe-inspiring natural wonders capture interest and imagination - from understanding the role of marine species in planetary function and stability to considering the possible utilisation of biological and genetic resources in research and development. ${ }^{3}$ Potential bio-inspired research and development, utilising or mimicking marine species, include: wound healing using jellyfish collagen; drug development using marine sponges; and soft robotics development inspired by seastars. ${ }^{4}$ Appreciation of the ecological, scientific, cultural and economic value of BвNJ, coupled with growing scientific evidence of catastrophic biodiversity loss and vulnerability to threats from human activities are driving mounting concerns about the conservation and sustainable use of вв в $^{5}{ }^{5}$

Marine technology transfer and capacity building form one of the four pillars of the ввNJ negotiations. Globally, gaps exist in terms of scientific knowledge of ABNJ and technological capabilities to monitor human activities in ABNJ. Furthermore, there are stark discrepancies in regional and national capacity

1 United Nations General Assembly Resolution 72/249. Resolution adopted by the General Assembly. International legally binding instrument under the United Nations Convention on the Law of the Sea on the conservation and sustainable use of marine biological diversity of areas beyond national jurisdiction. 72nd Sess, Agenda Item 77. UN doc A/REs/72/249.

2 Ludwig et al., 2011, 'U-Th systematics and 23oTh ages of carbonate chimneys at the Lost City Hydrothermal Field', Geochimica et Cosmochimica Acta 75(7) 1869-1888; Ramirez-Llodra, E., Brandt, A., Danovaro, R. et al., 2010, 'Deep, diverse and definitely different: unique attributes of the world's largest ecosystem', Biogeosciences, 7, 2851-2899; Dosi 2018. Deep Sea Fundamentals. Policy Brief September 2018. http://dosi-project.org/wp-content/uploads/2018/o5/ oog-Policy-Brief-3-Deep-sea-Fundamentals-DOSI-V3.pdf.

3 Snelgrove, P. V. R., 2016, 'An Ocean of Discovery: Biodiversity Beyond the Census of Marine Life', Planta Med. 82(o9/10), 790-799.

4 See for example Newman, D. J., 2016, 'Developing natural product drugs: Supply problems and how they have been overcome', Pharmacology and Therapeutics 162, 1-9; Pugliano, M., Vanbellinghen, X., Schwinte, P., Benkirane-Jessel, N., Keller, L., 2017, 'Combined Jellyfish Collagen Type II, Human Stem Cells and Tgf- $\beta_{3}$ as a Therapeutic Implant for Cartilage Repair', Stem Cell Res Ther 7: 4 DOI: 10.4172/2157-7633.1000382.

5 Merrie, A., Dunn, D. C., Metian, M., Boustany, A. M., Takei, Y., Oude Elferink, A., Ota, Y., Christensen, V., Halpin P. N., and Osterblom H., 2014, 'An ocean of surprises - Trends in human use, unexpected dynamics and governance challenges in areas beyond national jurisdiction', Global Environmental Change, 27, 19-31. 
to engage in marine scientific research and technological innovation, raising concerns about the ability of States to exercise their rights and fulfil their responsibilities under a future BBNJ agreement for example to implement areabased management tools and environmental impact assessments and to share in the benefits of marine genetic resources of ABNJ. ${ }^{6}$

As such, marine science and technology form the cornerstone of the discussions on capacity building and technology transfer. Other forms of capacity will also be important, such as policy and legal capacity, but the focus of this paper is the critical role of technology and scientific capacity in the development of the BBNJ agreement. First, the existing UNCLOS framework for marine technology transfer and the opportunities and challenges for scientific and technological capacity building for the BвNJ agreement is discussed. Second, the past experiences and potential future role of the Intergovernmental Oceanographic Commission of UNESCO (IOC) in matters relating to technology transfer under the ввNJ agreement are considered, using the clearinghouse mechanism as an example. Finally, opportunities to strengthen the implementation of UNCLOS through the BBNJ agreement and through initiatives such as the UN Decade of Ocean Science for Sustainable Development (2021-2030) are discussed. ${ }^{7}$

\section{Opportunities and Challenges}

The UNCLOs framework for the development and transfer of marine technology is established in Part XIV. Article 268 sets out the basic objectives of technology transfer, including:

a) the acquisition, evaluation and dissemination of marine technological knowledge and facilitate access to such information and data;

b) the development of appropriate marine technology;

c) the development of the necessary technological infrastructure to facilitate the transfer of marine technology;

d) the development of human resources through training and education of nationals of developing States and countries and especially the nationals of the least developed among them; and

6 Broggiato, A., S. Arnaud-Haond, C. Chiarolla, and T. Greiber, 2014, 'Fair and equitable sharing of benefits from the utilization of marine genetic resources in areas beyond national jurisdiction: Bridging the gaps between science and policy', Marine Policy 49, 176-185.

7 United Nations General Assembly Resolution 72/73. Resolution adopted by the General Assembly. Oceans and the law of the sea. 72 sess. Agenda Item 77 (a). UN doc A/RES $/ 72 / 73$. 
e) international cooperation, particularly at the regional, subregional and bilateral levels.

Based on this description, a very broad range of scientific and technological tools could be considered as relevant to technology transfer under the BBNJ agreement - ranging from scientific training and education, technological know-how, and access to infrastructure and equipment as well data, knowledge and information. There are provisions relevant to technology transfer and capacity building elsewhere in UNCLOS, including in Part XI (e.g., Article 143), Part XII (e.g., Article 202), and Part XIII (e.g., Article 244). Throughout, however, there a number of weaknesses and ambiguities that can be identified with respect to the UNCLOS framework for technology transfer and capacity building.

With the exception of the role for the International Seabed Authority that is specified in Part XI, UNCLOs does not provide any detail on the institutional mechanisms to deliver on technology transfer and capacity building. Nor does Part XIV provide: a financial mechanism to support technology transfer; modalities to identify technological need or request assistance; practical arrangements for information sharing, training opportunities and access to data; or a procedure to monitor the effectiveness of technology transfer programs, to strengthen and sustain components of the system and to promote long-term adoption. Rather, the measures referred to in Article 269 that are envisaged to achieve the basic objectives of technology transfer are heavily reliant on international science cooperation. Examples provided include conferences, exchanges and joint projects. This absence of implementation mechanisms is a concern for many States, given the fact that not all States have access to science and technology. 8

For the ввNJ agreement, scientific knowledge is crucial to make informed decisions about the conservation and sustainable use of ввNJ, and to enable a science-based approach. Biodiversity knowledge is important to designate and implement area-based management tools, conduct strategic environmental assessments and monitor and evaluate environmental impact assessment. For example, genetic tools show that fish populations once thought to be a single species are in fact genetically distinct - such findings have strong implications for conservation and sustainable use measures. These tools also create opportunities to understand and potentially harness genetic resources and deliver on access and benefit sharing. ${ }^{9}$

8 IOC. 2017. Global Ocean Science Report The current status of ocean science around the world, L. Valdés et al. (eds.). Paris, Unesco.

9 Harden-Davies, H., Gjerde, K., 2019, 'Building scientific and technological capacity: a role for benefit sharing in the conservation and sustainable use of marine biodiversity beyond 
The accumulation of new findings underscores that much remains to be discovered about BвNJ. This in turn is driving the development of new technologies to investigate the dark, deep and distant areas of the global ocean. For example, new genetic tools and robotics are being developed to investigate the ocean twilight zone, between $200 \mathrm{~m}$ and approximately 1,0oom deep. ${ }^{10}$ Submersibles and underwater robotics remain the purview of just a few research institutes worldwide - but technological innovation and the burgeoning field of open-source software and open-science are driving down costs and lowering the barrier to entry for States to engage in marine scientific research using new technologies.

Technology is also critical to monitor human activities, and to inform and support compliance measures. One such innovation is the use of the Automatic Identification System by governments, research organisations and civil society groups to monitor human activity at sea for applications relevant to the conservation and sustainable use of marine biodiversity. For example, AIs data has been used to address the impacts of anthropogenic noise, anchor scour and illegal, unreported, unregulated fishing. ${ }^{11}$

Public-private partnerships and philanthropic funding are playing a growing role in developing and transferring technology - as illustrated by examples such as the non-profit organisation Global Fishing Watch working with research institutes and government agencies in the use of AIS data. There is a need for business model innovation as much as technological innovation to fund the long-term development and deployment of ocean science and technology.

Ownership of scientific and technological infrastructure is not a prerequisite for accessing scientific knowledge. Access to data and knowledge is possible through decentralized data networks and information nodes. For

national jurisdiction', Ocean Yearbook 33(1), 377-40o; Rabone, M., Harden-Davies, H., Collins, J. E., Zajderman, S., Appeltans, W., Droege, G., Brandt, A., Pardo-Lopez, L., Dahlgren, T., Glover, A. G. and Horton, T., 2019, 'Access to marine genetic resources (MGR): Raising awareness of best-practice through a new agreement for biodiversity beyond national jurisdiction (BBNJ)', Frontiers in Marine Science. 6 10.3389/fmars.2019.00520.

10 See https://twilightzone.whoi.edu/ accessed 20 September 2019.

11 Erbe, C., Williams, R., Sandilands, D., Ashe, E., 2014, 'Identifying Modeled Ship Noise Hotspots for Marine Mammals of Canada's Pacific Region', PLOS ONE 9(3): e8982o.; Kroodsma, D. A., J. Mayorga, T. Hochberg, N. A. Miller, K. Boerder, F. Ferretti, A. Wilson, B. Bergman, T. D. White, B. A. Block, P. Woods, B. Sullivan, C. Costello and B. Worm, 2018, 'Tracking the global footprint of fisheries'. Science 359(6378): 904-908.; Davis, A. R., Broad, A., Gullett, W., Reveley, J., Steele, C., Schofield, C., 2016, 'Anchors away? The impacts of anchor scour by ocean-going vessels and potential response options', Marine Policy, 73, 1-7 https://doi.org/10.1016/j.marpol.2016.07.021. 
example, a volume of biodiversity data is available via the Ocean Biogeographic Information System (овIS), which is open-access and free of charge and the apparent fishing activity detected using AIs is available open-access on the website of Global Fishing Watch. Similarly, information and communication technology enables access to training opportunities via online courses and distance learning opportunities. As new technological opportunities develop, the importance of coordination and cooperation between the various national, regional and global nodes increases.

International science collaboration remains crucial to fund long-term sustained ocean observations, such as the Global Ocean Observing System (GOOs), and to deliver ambitious international programs in pursuit of policy objectives. Ocean observations are nationally funded, but coordinated via regional and global mechanisms linked under the Intergovernmental Oceanographic Commission of UNESCO (IOC). A clear example of the importance is the ambitious United Nations Decade of Ocean Science for Sustainable Development (20212030), currently in the preparation phase, designed to support the attainment of Agenda 2030 and Sustainable Development Goal 14 in particular. Though not the only UN agency with a role in marine science and technology transfer, the IOC is regarded as the primary competent international organisation for marine scientific research and plays a crucial role in coordinating international ocean science initiatives. In addition to Goos and the Decade preparation phase, IOC also coordinates other ocean science initiatives, regional ocean science cooperation mechanisms, data sharing platforms such as овIs, and training programs.

The IOC

The IOc has played an increasingly central role in the discussions on the topic of technology transfer and capacity building in the BвNJ negotiations - from the preparatory through to the current negotiation phase. As the lead international organisation for marine scientific research, the IOC also plays a role in technology transfer and capacity building, as illustrated by the Criteria and Guidelines on the Transfer of Marine Technology, ${ }^{12}$ and the document prepared by the IOC in response to a request from the African Group during the third session of the Preparatory Committee for the development of the BBNJ

\footnotetext{
12 IOC. 2005. IOC Criteria and Guidelines on the Transfer of Marine Technology. Paris, UNESCO.
} 
agreement..$^{13}$ The clearinghouse mechanism has been one of the key discussion areas in which the IOc has been engaged.

Although there is no single definition or vision for the clearinghouse mechanism as yet under the ввNJ agreement, a broad concept was laid out in the IOC CGTMT for a clearinghouse mechanism which, in essence, facilitates the sharing of information, access to expertise and promotes cooperation and coordination. It could also be considered to entail a proactive human element that actively facilitates connections between people and projects. ${ }^{14}$ It is of particular interest in the context of the $\mathrm{BBNJ}$ negotiations given the gaps regarding access to information and opportunity, and the strong interest in a mechanism to improve the transfer of marine technology under the BBNJ agreement.

There are a series of initiatives under IOC that perform functions that could be drawn upon for the BBNJ instrument. For example:

- Ocean Teacher Global Academy is a globally coordinated network of training and other capacity development mechanisms;

- Ocean Expert shares information about individuals, events, projects and profiles;

- Ocean Best Practices advances and promotes best practices and quality in ocean observations and data and is linked to the digital repository 'Ocean Docs';

- Ocean Data and Information System links data centres; and the

- Ocean Biogeographic Information System harvests and integrates biodiversity and related ecosystem data from more than 2900 databases all over the world and trains scientists in data management and analysis.

Furthermore, the regional hubs of the IOC provide a pre-existing institutional coordination mechanism for ocean science and technology transfer programs, such as the Regional Training and Research Centres of IOC wEstpac. However, the full potential role of IOC will be dependent on resources, something that has hindered the IOC in the past. ${ }^{15}$ As noted in the intervention delivered

13 IOC. 2017. Ad hoc Report of the Intergovernmental Oceanographic Commission (IOC) of unesco to the 4th Session of the Preparatory Committee on Marine Biological Diversity of Areas Beyond National Jurisdiction (ввNJ Prepcom) (New York, 10-21 July 2017), IOC Strategy on Activities in Relation to Capacity Development and Transfer of Marine Technology. IOC/INF - 1347. Paris, UnESCO.

14 IOC. 2018. IOC Group of Experts on Capacity Development. First Session, Paris, 21-23 March 2018. IOC/GE-CD-I/3. Agenda Item 4.6. 63-65.

15 H. Harden-Davies, 2016, 'Marine Science and technology transfer: Can the Intergovernmental Oceanographic Commission advance governance of biodiversity beyond national jurisdiction?', Marine Policy 74, 26o-267. 
by the IOC to the third session of the intergovernmental conference for the development of the B BNJ instrument:

All these systems currently operate on limited resources and a largely voluntary basis. Further operationalization will require resources and IOC is working on resource requirement identification. ${ }^{16}$

The B BNJ negotiations provide an important forum to discuss the potential opportunities and challenges of strengthening the legal, institutional and policy framework for technology transfer and building scientific capacity. The experiences of the IOC offer important guidance and lessons learned. Given that there are initiatives underway, yet still a sense that implementation must be strengthened, there is an apparent need to diagnose the problem behind gaps in technology transfer and capacity building. This is particularly timely given the opportunity provided by the UN Decade of Ocean Science for Sustainable Development to put a new paradigm of capacity building into practice and promote the implementation of the ввNJ instrument.

\section{$4 \quad$ Conclusion}

The technological tools of equipment, training materials and data access can be considered as a triple bottom line of scientific capacity building. However, the usefulness of these tools is largely dependent on scientific and technological capacity, and access to data and knowledge needs to be coupled with capacity development. The existing framework for the transfer of marine technology faces several challenges and gaps in implementation mechanisms that could be addressed by the BBNJ instrument. The experiences of the IOC in implementing the Criteria and Guidelines on the Transfer of Marine Technology can usefully inform the discussions on opportunities and challenges for the ввNJ agreement, including with regard to the clearinghouse mechanism. Making the most of opportunities requires knowledge of the capacity needs of States in addition to a procedure to monitor change.

16 Statement delivered by IOC-Unesco on Monday 26 August 2019. Third session of the intergovernmental conference for the development of a new international legally binding instrument for the conservation and sustainable use of marine biological diversity of areas beyond national jurisdiction under the United Nations Convention on the Law of the Sea. Agenda Item 6: Consideration of the subject matter referred to in paragraphs 1 and 2 of General Assembly resolution. Informal Working Group on capacity-building and the transfer of marine technology. United Nations, New York. 